\title{
Windthrow Resistance of Norway Spruce (Picea abies /L./ Karst.) Forest Cultures - Preliminary Results
}

\author{
Martina Đodan ${ }^{1 *}$, Sanja Perić ${ }^{1}$
}

(1) Croatian Forest Research Institute, Division for Silviculture, Cvjetno naselje 41, HR-10450 Jastrebarsko, Croatia

* Correspondence: e-mail: martinat@sumins.hr
Citation: ĐODAN M, PERIĆ S 2019 Windthrow Resistance of Norway Spruce (Picea abies /L./ Karst.) Forest Cultures Preliminary Results. South-east Eur for 10 (1): 77-88. DOI: https://doi.org/10.15177/ seefor.19-09

Received: 23 Mar 2019; Revised: 20 May 2019; Accepted: 24 May 2019; Published online: 7 Jun 2019

\begin{abstract}
Background and Purpose: Forest damage by wind is an important cause of economic loss in commercial forestry in the Republic of Croatia, as well as in many other European countries. Thus, windthrow resistance of trees represents a significant issue. Spruce forest cultures have shown the lowest resistance to windthrow so far. Nevertheless, there is not much insight into the relationship between trees and stand resistance to wind in the region. The objectives of this paper are to: (i) provide first evidence of the relation between tree characteristics prior to storm event in completely destroyed stands in comparison to slightly damaged stands, (ii) to evaluate the need to consider tree resistance to winds during thinnings, (iii) to evaluate if there is a need for windthrow stability assessment prior to replacement interventions.

Materials and Methods: The paper investigates three individual cases of spruce forest cultures on three localities in the hilly part of Central Croatia in the fifth decade of age. Two of three stands were completely destroyed by the storm event during the year 2013. The experiment was established in the spring of 2010 using randomised block design with three replications. Based on total tree height $(\mathrm{H})$ and diameter at breast height $(\mathrm{DBH})$ the following parameters were calculated: wood volume (V), basal area (B) and slenderness coefficient. Descriptive statistics and correlation analyses were made in STATISTICA 8.2.

Results: The results show overstocking, unfavourable structure and unfavourable slenderness coefficients (>80:1) in both cultures which were completely destroyed by wind. The correlation among variables revealed a significant relationship for all localities $(\mathrm{p}<0.05)$ when slenderness coefficient was compared with B and $V$ (negative), but there was no correlation with $\mathrm{H}$.

Conclusions: Research supported the claim that slenderness coefficient and stand structural analysis can be good predictors of damages caused by wind. With respect to the forthcoming increase of frequency and severity of storm events we propose to take evaluation of tree resistance into consideration prior to all silvicultural activities (especially high intensity interventions such as replacement/regeneration). Improved stability of trees against wind should be a silvicultural goal already from the first thinning (higher intensity thinings from below). In the case of unstable stands canopy cover should be opened cautiously to provide the remaining trees an opportunity to slowly respond to space increase. It should be noted that these initial findings should be supported by a more extensive research in the future.
\end{abstract}

Keywords: general stability, replacement, silvicultural guidance, thinning, afforestation

\section{INTRODUCTION}

Planted forests gain on their significance with the growing needs for timber, carbon sequestration and other non-wood products [1]. This is due to their high wood production and their role in loosening the production pressure from natural forests, acting as an important complementary, not their alternative [2]. In this respect Norway spruce (Picea abies /L./ Karst.) (further on - spruce) has a prominent role both in Europe [3] and in Croatia [4]. In addition, high occurrence of natural disturbances in natural forests adds to the importance of spruce monocultures through reforestation efforts. Moreover, 
due to their ameliorative role in preparing the site for stands with natural species composition [5], they have been highly important in afforestation and reforestation interventions for decades in Croatia.

Management driven exclusively by financial gain resulted with less input into silvicultural interventions in early stages of stand development. Because of this fact, growing stock was accumulated in many spruce cultures in Croatia [6]. In turn, this often left trees in a state of more competition and increased stress factors compared to trees in forest stands managed by "close to nature" principles. Problems related to low general stability of spruce cultures arose with the increase of storm events and bark beetle attacks. The avoidance of early thinning resulted in a stand structure, characterised by low tree vitality and unfavourable shape of trees, which showed higher susceptibility to the influence of windstorms. Forest damage by wind is an important cause of economic loss in commercial forestry for the Republic of Croatia as well as for many European countries [7-9], which is why windthrow resistance of trees represents a significant issue for all Croatian forests. Specifically, most of the annual cut in coniferous forest cultures is accomplished through sanitary and savage cuttings with lowered financial gains and lower value of wood assortments. In this respect, spruce cultures have had the highest share in salvage cut in recent years [6]. Reforestation is more expensive and includes more biological risks (in terms of soil loss, extreme influences on young plants etc.) in relation to timely replacement interventions. In turn, it has strong influence on stand properties and possibilities to regain natural composition of forests.

Research of windthrow stability of spruce stands is justified for several reasons. Firstly, the basic prerequisite for accomplishing productive and ameliorative functions of any forest culture is to maintain good vitality and achieve good production and general stability up to the end of stand rotation [6]. In addition, in the anthropogenic forest cultures characterized by decreased stability there is a good chance that at the end, or even well before the end of the rotation period, shelter of mature trees could be lost due to stem breakage or uprooting. At the time of conversion canopy cover should be opened significantly (by regeneration cut) in order to provide optimal light and temperature conditions for seedlings and saplings. This silvicultural activity further increases negative forcing on the remaining trees, increasing the risk of total canopy loss. Gaining insight into stability indices of present forest cultures enables us to prescribe silvicultural guidelines and to modify them according to predicted climate changes. These are the basic principles of contemporary silvicultural efforts, which are part of adaptive forest management (AFM) [10-12]. Secondly, in spite of numerous benefits, spruce is sensitive to different aspects of the changing climate $[4,5]$, especially abiotic influences such as wind, snow and ice loads mainly due to its shallow root system [3]. In this respect, the shape of trees can be crucial for the severity of disturbances [13]. Furthermore, negative climate influences are predicted to become more frequent and severe in the future, further adding the pressure to planted forests. Storm occurrences already increased in the last decade [14]. Climate change is not only likely to affect the growth of trees and stands but every aspect of forestry, including some of the fundamental methods employed in silviculture, such as thinning $[15,16]$.
Besides basic structural parameters such as the basal area, tree slenderness is also a measure recognised as a good indicator of the windthrow stability of trees [17]. The shape of trees can be influenced by silvicultural interventions, if applied early in the stand development. It indicates the "shape" of trees and together with tree vitality provides insight into general stability of planted forests. Spruce cultures are, because of their high productivity and easy establishment, well investigated in Croatia [4]. Nevertheless, there is no research connecting structural parameters, especially tree slenderness in stands devastated heavily by windstorms with stand structure and slenderness prior to devastation. Tree slenderness is used to predict sensibility to wind and storm events for conifer species for a number of years [17]. Despite significant damages caused by the windstorms in the last couple of decades, there has been little insight into the relationship between trees and stand resistance to winds in Croatia. Only Oršanić [5] investigated the structure of planted spruce forests in 1995, which are especially prone to this kind of damages. At very high speeds, wind can devastate forest stands independent of stand structure attributes such as density, species or tree dimensions [18]. Nevertheless, at lower wind speed stand structure is crucial [19]. Spruce cultures were selected because of: (i) their high importance for the country due to their high wood production [4-6], (ii) high sensitivity of spruce to climate changes, especially storm and drought events [20], (iii) higher management pressure in relation to natural stands, (iv) their high importance in preparation of the site for the retrieval of autochthonous tree species or reforestation after disturbances.

All of these facts raised the question in which cases spruce cultures should be immediately replaced [6], and which could be thinned to the end of rotation period to provide for the set managed goals and justifies the initial invested financial efforts. Thus, the paper investigates three individual cases of anthropogenic spruce stands in the hilly part of Central Croatia, two of which were completely destroyed by the storm event during the year 2013. The third withstanded the wind more successfully. The specific objectives of the paper are to: (i) provide first evidence of the relation between tree characteristics and the stability of spruce trees against winds prior to the storm event in completely destroyed spruce cultures, in comparison to slightly damaged stands, (ii) to evaluate the need of appropriate silvicultural interventions (especially early thinnings) in spruce cultures and to evaluate the need to consider resistance of trees to winds, (iii) to evaluate if there is a need for windthrow stability assessment prior to replacement interventions to prevent further financial and biological losses. The presentation of these first results aims at unravelling the way by which risks during the replacement of susceptible spruce cultures can be determined. Furthermore, it aims at assessing actual needs for the exclusion of such cultures from further management through immediate replacement with more resistant and resilient mixed species forest stands.

\section{MATERIALS AND METHODS}

\section{Research Area}

Research was conducted on three localities in central part of Croatia. The source of information on climate, relief, and 
past management were forest management plans [21, 22]. Specific trial plot data (e.g. inclination, altitude, exposition and soil characteristics) were gathered in the field (Table 1). Experimental plots on localities $A$ and $B$ are situated in the hilly area, on mild slopes, in the vicinity of Jastrebarsko (170-184 $\mathrm{m}$ a. s. I.). These trial plots have mild inclination $\left(0-10^{\circ}\right)$ and south-west exposition. Climate of the area is warm to moderately humid (Cfwbx" according to Köpen). Winters are cold, summers are fresh, while the climate is altogether humid. Mean temperature of the coldest month ranges between $18^{\circ} \mathrm{C}$ and $-2^{\circ} \mathrm{C}$. Winter is the driest part of the year, while the rain period is divided into spring (April to June) and autumn maximum (October). Mean annual air temperature is $9.8^{\circ} \mathrm{C}, 19.8^{\circ} \mathrm{C}$ in the warmest month (July) and -1.1 in the coldest month (January). Precipitation is evenly distributed during the year, with an exception of the maximum in June (96 mm) and autumn (94 mm). Mean annual precipitation in vegetation period is $87 \mathrm{~mm}$ (monthly values). The bedrock on the area consists of quartz sands, gravel and clay, while the predominant soil types are pseudogley, illimerized soil on loess and dystric cambisol (with inclusions of eugley and colluvium). From the aspect of potential vegetation this is the area naturally dominated by mixed European hornbeam - sessile oak forests (Carpino betuli-Quercetum roboris typicum Rauš 71).

Experimental plots on locality $\mathrm{C}$ are located on the north-west slopes of Medvednica Mountain in the vicinity of Zagreb. Climate of the area is the same as on the localities $A$ and B (Cfwbx" according to Köpen). Mean annual air temperature is $6.2^{\circ} \mathrm{C}$. The lowest temperatures of the area (below $0^{\circ} \mathrm{C}$ ) appear in the months from September to December and from January to May. Mean temperature of the coldest month ranges between $18^{\circ} \mathrm{C}$ and $-2^{\circ} \mathrm{C}$. Winter is the driest part of the year, while the rain period is divided into spring (April to June) and autumn maximum (October). The temperature of the warmest month (July) is $19.8^{\circ} \mathrm{C}$, and of the coldest month (January) it is -1.1. The duration of the vegetation period is limited by the temperature threshold with the average daily temperature of $10^{\circ} \mathrm{C}$ (from 192 up to 200 days). On this area the mean annual air humidity ranges from 77 up to $83 \%$. Annual rainfall amounts to $1249 \mathrm{~mm}$ ( $700 \mathrm{~mm}$ or $56 \%$ in the vegetation period). Predominant pedosystematic unit is formed by dystric cambisol on methamorphic and clastic rocks. From the aspect of potential vegetation area the surrounding of the spruce monoculture is naturally dominated by mixed silver fir - European beech forests (Festuco drymeiae-Abietetum Vukelić et Baričević 2007). The main wind directions are SE (5\%) and NW - N with $22.4 \%$ of occurrence. This area has double average value of wind intensity (according to Beaufort) than the rest of the surrounding lowland area.

\section{The Experimental Design}

The experiment on spruce cultures was established in the spring of 2010 using a randomised block design with three replications. In these field tests, three trial plots $(10 \times 10 \mathrm{~m})$ were set in spruce monocultures on localities $A$ and $B$, while on the locality $C 16$ plots were set $(10 \times 10 \mathrm{~m})$. More detailed description of the experimental plots and site conditions are provided by Tijardović [6]. Despite the fact that trial plots were relatively small (three repetitions $10 \times 10$ evenly distributed on the area of studied spruce culture) we would like to emphasize that the structure of cultures is one-layered and very homogenous both in vertical and horizontal sense. The high homogeneity throughout whole spruce cultures is so high that there was no real need to include large trial plots (e.g. $0.25 \mathrm{ha}$ ) as it is usually used for determining the structure of heterogeneous forests. All investigated spruce monocultures were in the fifth decade of age based on the age of individual spruce trees determined through the analysis of tree rings (on felled trees during thinning and sanitary cuts). Prior to the establishment of spruce monocultures on localities $A$ and $B$ the area was used for forestry purposes, while the area of locality $A$ was affected by forest fire and reforested (mixed silver fir-European beech forest). Spruce cultures on localities A and B were thinned only by sanitary cuts, while spruce culture on locality $C$ was regularly thinned (selection thinning).

\section{Field Measurements and Statistical Analysis}

For this research total tree height $(\mathrm{H})$ and diameter at breast height $(\mathrm{DBH})$ were measured manually in the year 2010 (fifth decade after the establishment of cultures). Based on $\mathrm{DBH}$ and $\mathrm{H}$, wood volume $(\mathrm{V})$, basal area $(\mathrm{B})$ and slenderness coefficient wood volume were calculated. Wood volume was calculated using local tariffs. Descriptive statistics for all parameters and the tested correlation were calculated (type I error $(\alpha)$ of $5 \%$ was considered statistically significant). H/DBH ratio (slenderness index) is as an indicator of the stem form [23] and is calculated rather easily, but both values have to be in the same unit (e.g. m). Regarding the fact that immense spruce decline appeared near trial plots, the vitality of trees was also determined and analysed (in two degrees: 1 - healthy trees, slight or moderate crown defoliation, $<60 \%$ of needle loss; 2 - severe defoliation or dead trees, $>60-100 \%$ of needle loss including needle yellowing). All analyses and graphs were made by using STATISTICA 8.2 statistical programme [24].

TABLE 1. Basic information on anthropogenic Norway spruce forest cultures included in the research.

\begin{tabular}{|c|c|c|c|c|c|}
\hline Locality & $\begin{array}{c}\text { Study plot } \\
\text { code }\end{array}$ & Coordinates & Altitude (m) & Inclination $\left({ }^{\circ}\right)$ & Exposition \\
\hline Dornja Kupčina & A & N 4538'33.3"; E 15³3'41.9" & $182-184$ & $0-10$ & SW \\
\hline Izimje & B & N 453'12.1"; E 15³4'16.6" & $170-177$ & $0-10$ & SW \\
\hline Bistranska gora & C & 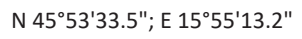 & $729-740$ & $10-30$ & $\mathrm{~N} / \mathrm{NW}$ \\
\hline
\end{tabular}




\section{RESULTS}

\section{General Description of Studied Spruce Cultures and Tree Slenderness}

The results showed that, on average, trees were more slender on localities $A$ and $B$ in comparison to locality $C$ (Figure 1). On trial plots on locality A Norway spruce is also the sole tree species (100\%), but this forest culture is denser than the aforementioned culture. From $\mathrm{DBH}, \mathrm{H}$ and their ratio, it was determined that not one tree has favourable slenderness coefficient (ratio<80:1). Trees with slenderness in border classes summed up to 5.5\% (80:1 to 90:1). Even trees with values higher than 200:1 were found. Consequently, almost all trees in this subdepartment have been uprooted due to the storm event in 2013, which was the year when measurements were completed. Out of 181 trees 143 trees were healthy (79.01\%), while the remaining 38 trees were dead $(21 \%)$. Mean tree volume on the trial plots amounted to 0.14 , with minimum value of $0.01 \mathrm{~m}^{3}$ and maximum of $1.73 \mathrm{~m}^{3}$ (Figure 2). Descriptive statistics for all parameters and localities is given in Table 2 .

In all three repetitions on locality $B$ the only tree species in the stand was spruce $\left(154\right.$ trees on $\left.3 \times 100 \mathrm{~m}^{2}\right)$, which makes this forest culture a monoculture. Total tree height $(\mathrm{H})$ and DBH ratio is unfavourable for $98 \%$ of trees $(>80: 1)$, while $11.9 \%$ of trees are in border slenderness classes (80:1 to $90: 1)$. The vitality of trees shows that $74 \%$ or 114 trees are healthy, while $26 \%$ or 40 trees are in the highest degree of decline (totally dead). Mean tree volume on trial plots has the lowest value out of all localities and amounts to 0.04 $\mathrm{m}^{3}$, but with the smallest standard deviation $\left(0.05 \mathrm{~m}^{3}\right)$. On trial plots as many as 47 trees are thinner than $7 \mathrm{~cm}$, which makes $30.5 \%$ of total tree number.

According to species mixture, forest culture on locality $\mathrm{C}$ is mixed Norway spruce-silver fir forest culture. Out of 144 trees on trial plots $\left(1600 \mathrm{~m}^{2}\right) 108$ or $75 \%$ are spruce trees, $19.4 \%$ or 28 silver fir trees and the remaining $5.6 \%$ includes European beech, European hornbeam and maple. Forest culture on this locality is characterised by higher dimensions and better slenderness coefficient of spruce trees. Favourable slenderness coefficient possesses 51.4\% of trees, while $21.49 \%$ are in border values (80:1 to $90: 1$ ). No trees were registered in slenderness class above 150:1. Tree volume on this locality has the highest value and amounts to $0.42 \mathrm{~m}^{3}$, with the maximum value of $1.62 \mathrm{~m}^{3}$. Basal area is also the highest with $0.051 \mathrm{~m}^{2}$, showing the highest standard deviation $\left(0.04 \mathrm{~m}^{2}\right)$, as well as the highest standard deviation of volumes $\left(0.38 \mathrm{~m}^{3}\right)$. Registered trees lower than $7 \mathrm{~cm}$ were mainly silver fir trees, which spontaneously appeared in the forest culture. Even though all trees were healthy at the beginning of the research (in 2010), around $25 \%$ of trees died out in the next three years due to bark beetle outbreak.

TABLE 2. Descriptive statistics for all analysed parameters and localities.

\begin{tabular}{|c|c|c|c|c|c|c|}
\hline Locality & $\begin{array}{c}\mathbf{N} \\
\text { (number of trees on sample plots) }\end{array}$ & Variable & Mean & Minimum & Maximum & $\begin{array}{l}\text { Standard } \\
\text { deviation }\end{array}$ \\
\hline \multirow{5}{*}{ A } & \multirow{5}{*}{181} & $\mathrm{DBH}(\mathrm{cm})$ & 9.8 & 1 & 22 & 4.56 \\
\hline & & Tree height $(\mathrm{m})$ & 11.56 & 1.7 & 18.8 & 4.51 \\
\hline & & Basal area $\left(\mathrm{m}^{2}\right)$ & 0.019 & 0.00008 & 0.038 & 0.008 \\
\hline & & Tree volume $\left(\mathrm{m}^{3}\right)$ & 0.05 & 0.001 & 0.26 & 0.06 \\
\hline & & Slenderness coefficient & 123.1 & 62.5 & 325 & 26.8 \\
\hline \multirow{5}{*}{ B } & \multirow{5}{*}{154} & $\mathrm{DBH}(\mathrm{cm})$ & 9 & 2 & 20 & 4.48 \\
\hline & & Tree height (m) & 9.47 & 1.9 & 16.9 & 4.14 \\
\hline & & Basal area $\left(\mathrm{m}^{2}\right)$ & 0.008 & 0.0003 & 0.031 & 0.007 \\
\hline & & Tree volume $\left(\mathrm{m}^{3}\right)$ & 0.04 & 0.001 & 0.25 & 0.05 \\
\hline & & Slenderness coefficient & 109.6 & 30.8 & 162.7 & 18.5 \\
\hline \multirow{5}{*}{$\mathrm{C}$} & \multirow{5}{*}{108} & $\mathrm{DBH}(\mathrm{cm})$ & 23.3 & 7 & 46 & 10.45 \\
\hline & & Tree height (m) & 18.02 & 4.9 & 25.9 & 6.63 \\
\hline & & Basal area $\left(\mathrm{m}^{2}\right)$ & 0.051 & 0.004 & 0.166 & 0.04 \\
\hline & & Tree volume $\left(\mathrm{m}^{3}\right)$ & 0.42 & 0.01 & 1.62 & 0.38 \\
\hline & & Slenderness coefficient & 80.9 & 52.2 & 135 & 15.1 \\
\hline
\end{tabular}



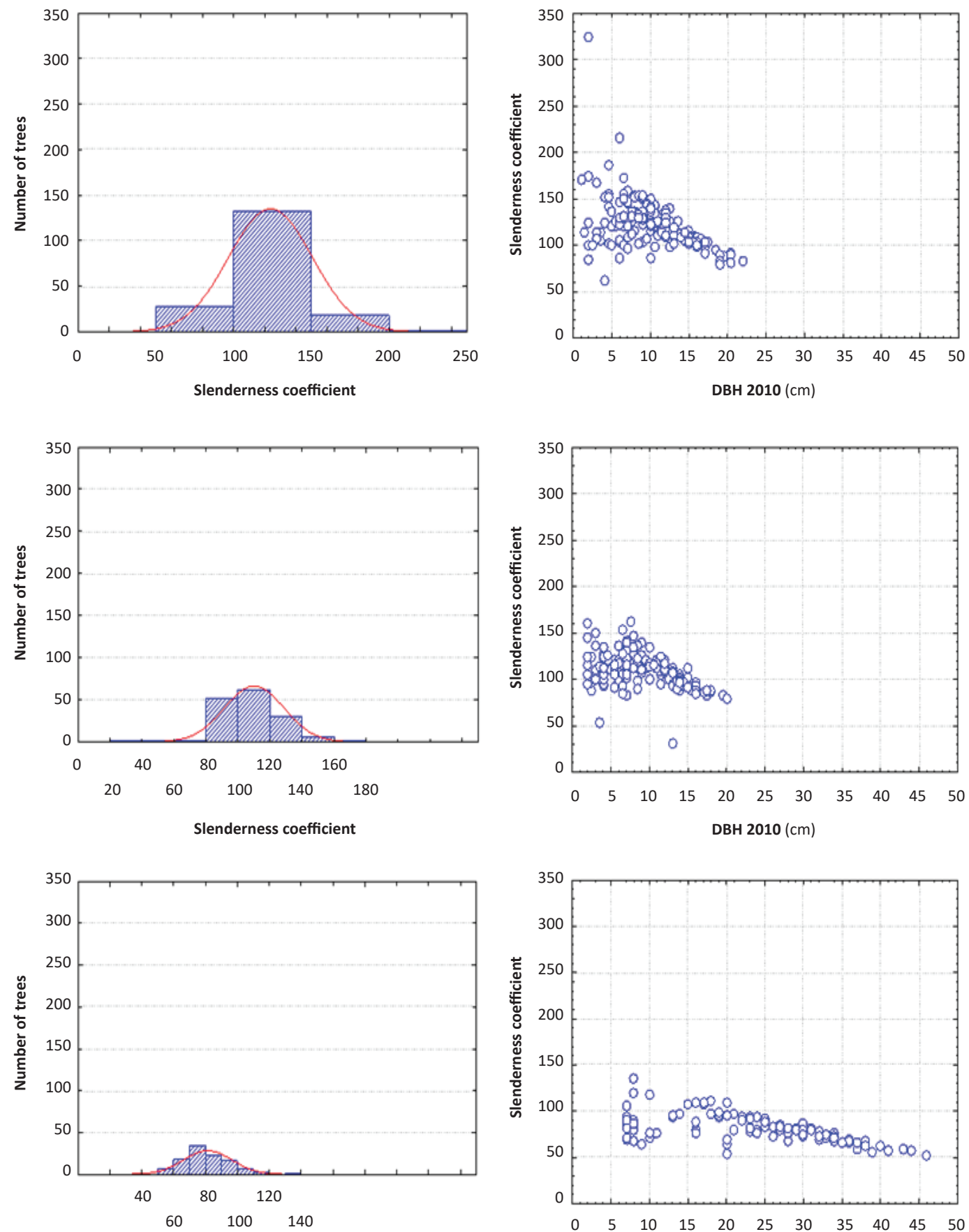

Slenderness coefficient

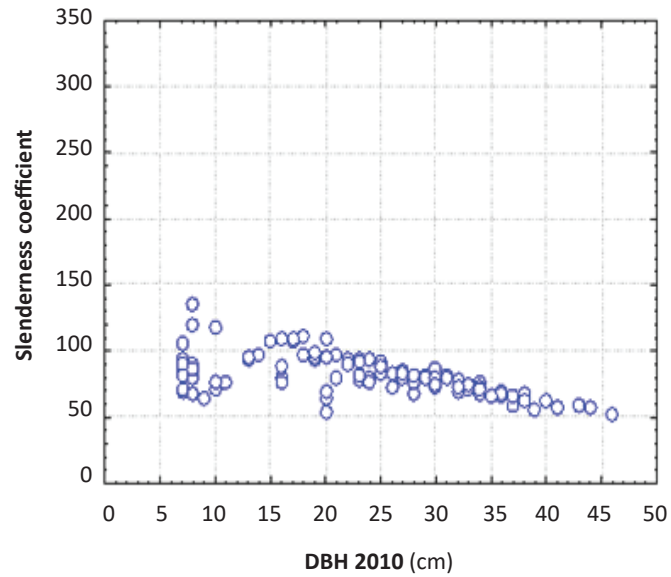

FIGURE 1. Distribution of trees according to tree slenderness for the three spruce cultures included in the study (location A upper, location B - middle, location C - bottom). 

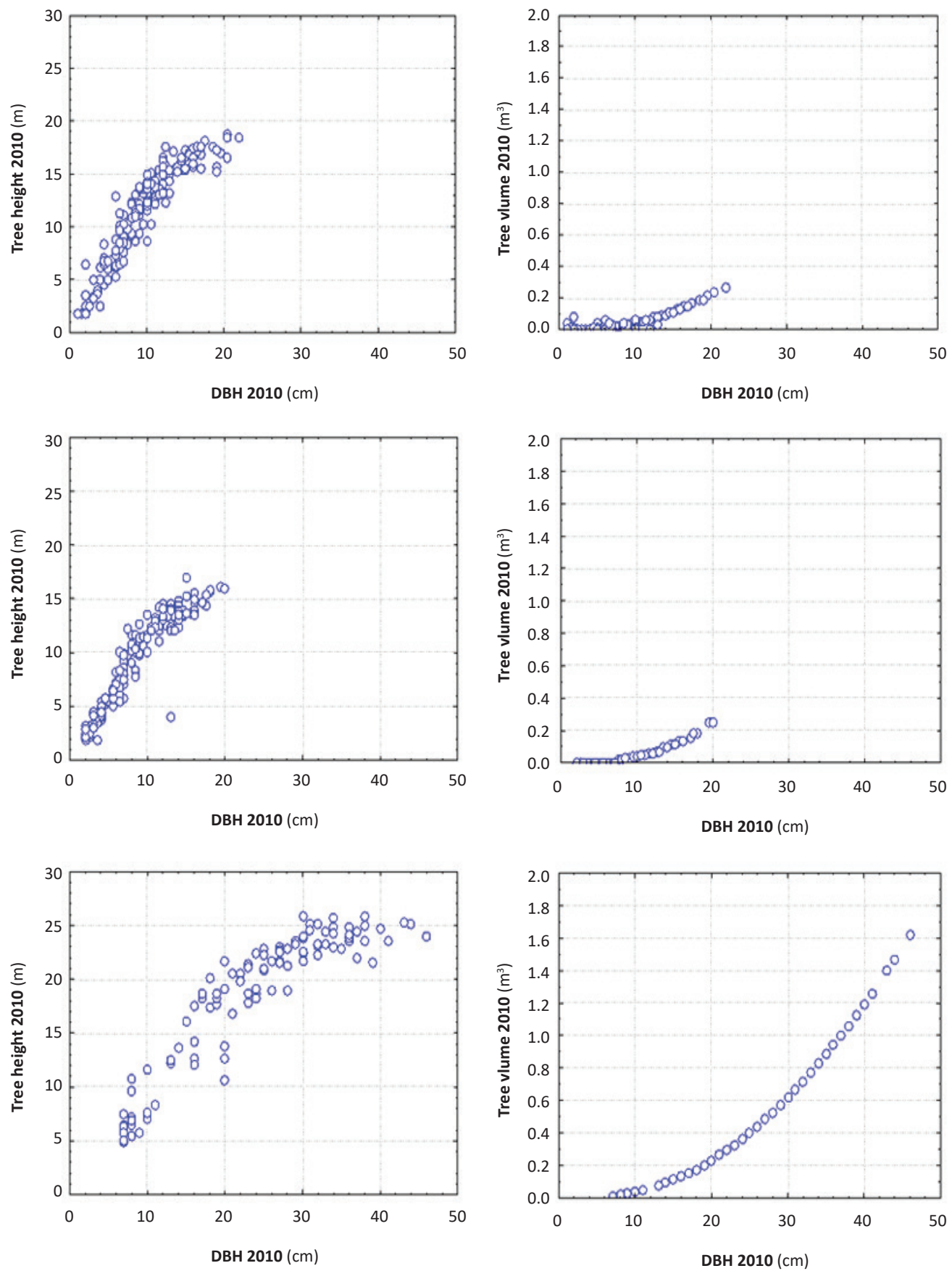

FIGURE 2. Distribution of trees according to diameter at breast height and tree volume (location A - first row, location B - in the middle, location $\mathrm{C}$ - bottom row). 
Correlation of Tree Slenderness and Structural Parameters

The correlation among variables revealed the significant relationship for all localities $(p<0.05)$ when slenderness coefficient was compared to basal area and tree volume. There is no significance in correlation with tree height $(r$ ranged from -0.10 to -0.35$)$. The correlation between slenderness coefficient and tree volume is negative for all tree localities.

\section{DISCUSSION}

The Need to Address Windthrow Resistance of Trees

Besides productivity and financial gain, one of the most important roles of spruce cultures is their ameliorative role of preparing the soil for autochthonous late successional tree species, as well as protecting them from adverse climatic influences $[4,5]$. The need for planted forests (forest cultures) will increase in the future [25]. Thus, importance of forest culture stability is especially relevant at the end of the rotation period. Nevertheless, significant intrusion into the structure of forest cultures caused by seeding cut, which could not be avoided because optimal conditions for seedlings and saplings have to be provided, additionally exposes trees to wind [13]. Therefore, for Norway spruce, as a tree species with shallow, plate-like root system, which is especially prone to uprooting and stem breakage, determination of stability against wind is a basic prerequisite of meeting the set production goals. It is crucial for successful replacement of spruce cultures as well. Mast years additionally influence crown instability [5], while other possible negative influences are former management, bark beetle and fungi presence, damages which emerged during cutting and wood exploitation, site pollution and global climate changes [26].

There is a need to investigate and to create a method of assessing the risk of wind damage since it could have an important influence on silvicultural decision making, especially in terms of climate change adaptation strategies. Dobbertin [27] finds that the probability of damage increased with stand height, development stage, percentage of conifers, soil-water logging and soil depth in the areas affected by Vivian (in the year 1990) and Lothar (in the year 1999) storms. Some authors propose the replacement of pure stands (especially in the case of spruce) into mixed stands to enhance stand stability $[5,7]$. Comparative research of mixed forest cultures comprised of spruce and broadleaved tree species (minimal share of broadleaves $20-40 \%$ ) and spruce monocultures, showing that mixed cultures can support ecological, economic, social and cultural benefits and functions in the same or even better way than monocultures (30-40\%). In addition, mixed forest cultures possess better chemical conditions and better organic matter decomposition on forest floor. Since this is generally highlighted as a prominent disadvantage of spruce cultures, admixing tree species could have a positive effect on general stability as well. Even though admixing beech into spruce monocultures resulted in growth stimulation, this depends strongly on site conditions [28-32]. Therefore,

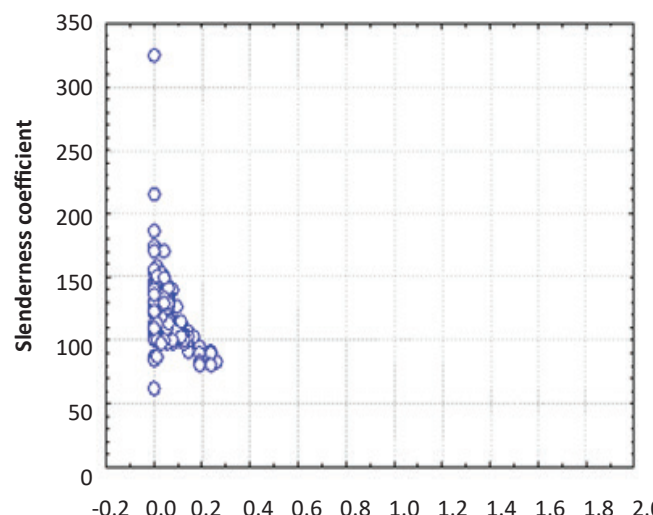

Tree vlume $2010\left(\mathrm{~m}^{3}\right)$
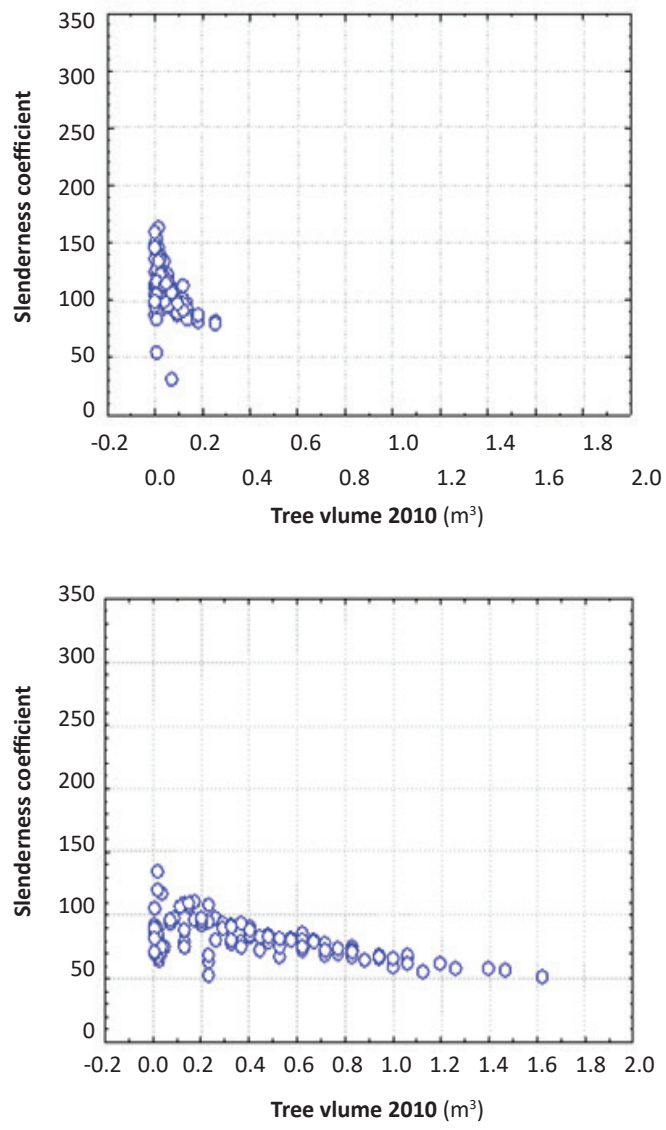

FIGURE 3. Dependence of slenderness coefficient and volume for studied spruce cultures on all localities (location A - top, location B - middle, location C - bottom). 
this should be further investigated especially in the Republic of Croatia where these kinds of research are scarce. The combination of broadleaved tree species admixed into a spruce monoculture can be diverse and they depend on elevation. For example, spruce can be mixed with silver birch, Acer pseudoplatanus (L.), and small-leaved lime [5, 33-38]. In addition, conifers are more sensible and possess lower stability threshold in comparison to broadleaves. They retain needles during the winter, which has significant effect on static stability (the so-called "wet snow"), but also on the collection and retainment of pollutants which can be even three times greater than in stands consisting of broadleaves [39-43]. Species mixtures could present better solution for the production, amelioration and enhancement of stability. Related studies are scarce even at the European level.

Projected changes in precipitation and air temperatures from Meteorological and Hydrological Service of the Republic of Croatia point to the unfavourable trend for the areas of mountain and central part of the country, enhancing negative effects on forest ecosystems [44, 45]. In addition, in the last few years an increase of storm events occurrence was recorded on the whole continent, while the predictions point to even quicker rise in the future [14]. Lower frequency of soil freezing from late autumn to early spring, which is the period with highest wind occurrences, will increase wind damages in the future [46]. Other influences of global warming on forest cultures are yet to be further investigated $[47,48]$. In the Republic of Croatia, there is a lack of scientific research which aims at developing instruments for estimation of storm occurrences, sensibility of forests to climate changes, as well as instruments for management adapted to such changes. In some European countries such instruments have already been developed and first successful application has been recorded [13, 49-53]. Significant loses in natural forest stands proved that damages caused by wind, snow and ice are a major disturbance interacting with forest development processes, which is why there is a strong need for this kind of research and its predictions.

Regarding the age of studied stands it can be pointed out that the avoidance or too low thinning intensities have irreversible influence on the spruce culture in the fifth decade (probably even earlier, but this has not been proven by the study). Thus, we stress the importance of appropriate species composition and the importance of early thinnings for the achievement of optimal tree characteristics, vitality, and for accomplishing the expected biological and financial gains altogether. The collected data are applicable to the hilly part of Central Croatia, for which the need of addressing stability issues is emphasized.

\section{Indicators for the Evaluation of Stability of Spruce Trees against Winds}

Basal area and tree slenderness have been used for the prediction of sensibility to wind and storm events for coniferous species for a number of years [17, 54-56]. However, this statement is true for the countries dealing with damages from strong winds for decades, while in Croatia there is a weak insight into indicators of tree resistance to winds. Tree slenderness, together with stand density data, are also needed for predictions of critical wind speeds needed for the uprooting of trees, which can be an important predictor for risk from wind damages and related management decisions. Even though stability can be predicted on the basis of crown dimension parameters (crown length and tree height ratio, crow diameter and DBH ratio, etc.), in regions with frequent snow occurrences such as the investigated areas this indicator is not accurate enough [14]. Thus, the parameters based on other tree dimensions such as basal area or tree slenderness are proved to be better predictors. Studies of tree slenderness are limited for Croatia [5] and tree resistance to winds or tree slenderness is not taken into account in regular thinning interventions. This study provided first results on the appropriateness of tree slenderness as a predictor of wind damages. The destruction of spruce cultures with the highest values of slenderness in the study was total, while spruce cultures with more favourable tree slenderness that withstanded the same storm were more successful. Regarding tree characteristics, the highest and the slenderest subjects were the most sensitive, both in terms of stem breakage and overturning. This is also proved in the studies by Peltola et al. [46] and Talkkari et al. [57]. These preliminary data should be further supported by more extensive research (e.g. including more localities, wind characteristics, etc.), especially since the importance of wind damages and the role of thinning intensities will grow in the future, and since the current insight into these issues on the national scale is weak. Interesting cases are pure forest stands in sinkholes, where spruce presents the best silvicultural option for the frost-prone areas. Here, special consideration should be given to the further studies on wind susceptibility and the related silvicultural interventions needed to enhance the stability of spruce cultures.

Regular thinning in cultures in completely destroyed trial plots on localities A and B was not conducted, while sanitary and salvage cuttings were. Research of structure on localities $A$ and $B$ pointed to high instability as a result of unconducted or inappropriate thinnings pointing to overstocking. Ratio 80:1 presents stability threshold for conifer species $[46,55]$. On locality A, data analysis showed the most unsatisfactory structure. There was not one tree on the trial plots which had favourable slenderness coefficient $(<80: 1)$, while trees with ratio $>200: 1$ were also recorded. On the selected trial plots, it is not justifiable to do conversion into climax tree species, so it can be concluded that basic goals set at the time of culture establishment were not met (the sites' ameliorative function was not met). That is also true if relatively low productivity or the value of the assortments are taken into account (average DBH in 45 years of age was $9 \mathrm{~cm}$ on locality $A$ and $13 \mathrm{~cm}$ on locality B). High interspecific competition in soil up to $80 \mathrm{~cm}$ in depth and increased retention of precipitation on the canopy (lower amount of water that reaches soil [58]) are a direct result of a too high number of trees per hectare $\left(\mathrm{ha}^{-1}\right)$ caused by improper management. Lack of tending measures resulted with additional negative forcing and, consequently, increased the sensibility of trees to bark beetle attack, which was also evidenced on trial plots. High correlation of damages caused by wind and tree slenderness 
is also confirmed by Peltola [59]. The structure on locality $\mathrm{C}$ is more favourable in relation to the aforementioned localities. This culture was regularly thinned, which points to the conclusion that there is an influence of thinning on the formation of better tree characteristics. A slightly higher slenderness coefficient in another culture on Medvednica was found by Oršanić [5].

Thinning throughout the whole rotation period is a prerequisite for successful replacement as well. Good windthrow stability is needed for conversion under shelterwood when autochthonous late successional tree species composition is set as a silvicultural goal. Nevertheless, this is often neglected in management of forest cultures in the Republic of Croatia, and the resistance of trees to strong winds is not acknowledged as it should be. In addition, a better understanding of the reaction to thinning is important in order to design new thinning regimes in a changing environment [60]. Also, in some studies, the resistance of trees described by their slenderness is not only higher for suppressed than dominant trees of a particular stand, but the data indicate that slenderness is also notably smaller for trees grown under wider spacing [7]. This statement can have implications for future establishment and tending of forest cultures in terms of spacing and horizontal spatial pattern (for example, in mixed forest cultures) and it is proven with this study as well. Dominant trees possess higher stiffness in lower stem parts than supressed trees [7], so it is evident that in overstocked forest cultures without optimal vertical structure the risks of windthrow will be higher.

The Role of Silvicultural Interventions in Increasing Stand Resistance to Wind and the Need for Further Research

Basic structural characteristics (height, stem taper) are quite variable and change considerably for spruce under different silvicultural treatments [7], which implies great significance of proper and timely thinnings. This study adds tree slenderness as an important and additional characteristic, which can be influenced by proper silvicultural interventions.

Statistical analysis of the simulation results showed that wind speed is the most significant variable in explaining wind damage [8], thus pointing to the conclusion that the resistance of trees to wind can be influenced only upon certain "wind speed threshold". Up to the critical "wind speed threshold" we can and should influence positively the forming of more resistant trees. If the critical wind speed is set, that gives us the possibility to intensify the thinnings and management activities in the area with bigger risks. This, besides thinning, also incorporates better selection of tree species or species mixtures. Spatz and Bruechert [18] provide mechanistic explanation why structure is crucial. Both gravitational forces and wind loads induce bending moments, which the structure has to be able to withstand. The limit of the structure is reached if at any point the bending moment induced is larger than the critical bending moment. This in turn depends on structural parameters (the geometry of the cross-section) and properties of the material (the modulus of elasticity and the critical stresses at which failure occurs). In many cases, depending on the root-soil interaction, the bending moment on the trunk may lead to root lodging. In addition, bending under wind loads will lead to additional bending moments under gravitational loads. Whereas the young generation depends on the vitality as a prerequisite for snow and ice load resistance and flexibility, the manuscript does not tackle the youth because of the age of the stands included in the study. The expansion of research to the young generation is important to be tackled in future, especially the vitality of youth determined in the light of the growth and development of forms depending on light revealing the Honowsky index. The development of tree shape in relation to light is more complex in irregular forests as shown by Szymura [61], but the stability of irregular forest stands in relation to negative wind forcing is the highest among all silvicultural systems. Furthermore, despite the fact that these initial results reveal the relationship between tree shape and susceptibility of stands to the influence of wind, the relationship between stability and vitality should be included in further research efforts. Available studies mostly tackle tree vitality. For example, defoliation [62] and influence of drought [63] can improve prediction accuracy of models that predict tree mortality based on competition indicators and tree size alone, not taking wind damages into account. While it is known that negative influence of wind is affecting both healthy trees and trees with low vitality, and that crown recovery can be an important feature of tree recovery [64], research that would explain in detail the connection between tree vitality and susceptibility to wind would be very complex. Thus, there is a lack of scientific research which would shed more light on the connection of tree vitality and windthrow stability.

Talkkari et al. [57], for example, estimate the risk of wind damage by employing complex mechanistic models for predicting the critical wind speed needed to cause damage, a regional air flow model simulating relative wind climates for sites, a geographical database on forest stands in the area concerned and the probability distribution of longterm extremes in wind speed at the sites. This approach is well adapted to regular stands, but if one wants to adapt silvicultural measures in heterogeneous stands, not all trees are necessarily damaged at the same time and this kind of predictions are less accurate [8]. In Croatia there are no similar findings emphasizing the need to further proceed with research on these issues. From the aspect of stability, mixed stands also present a more or less heterogeneous forest structure, and have yet to be more investigated in the future. This kind of research is needed in the Republic of Croatia if the increase of storm occurrence is to be taken into account. Further investigations on the influence of soil type on forest damage are, however, generally required [27], and not only in the Republic of Croatia.

The existing knowledge emphasizes that the greatest risks are found in forest stands immediately after thinning or after regeneration cuts, and that risk is present in those stands which have not been thinned properly or are suddenly drastically thinned $[65,66]$. This is why we advise that spruce stands in the same age as investigated, with similar structure, should not be further maintained, but should be immediately replaced, in order to lower biological and financial losses. In turn, we strongly advise that all newly established as well as young spruce cultures 
should be thinned regularly with respect to tree and stand resistance to wind.

Finally, it can be concluded that the monitored forest cultures possess high risks regarding replacement since their low resistance against wind prevents them to protect young and sensitive late successional tree species. Similar risks during conversion have been found by Lüpke et al. [3] in other parts of Europe. These findings evidently point to the fact that by influencing the forest structure we can enhance not only mechanical stability, but tree vitality and general stability as well. This can be accomplished through correct site selection and adequate afforestation practices, as well as appropriate tending throughout the whole rotation period. All these measures are crucial for the fulfilment of basic functions and goals, which are set at the time of the establishment of a forest culture. We also advise the evaluation of culture resistance to winds prior to the replacement, so that the aimed tree species composition could be selected accordingly (e.g. if the resistance is low the need to provide protection for late successional tree species against sunburn, frosts, wind and drought should be respected). In the conditions of unfavourable structure, it is strongly recommended to open canopy cover cautiously. For example, canopy cover can be opened only above regeneration areas ( 400 to $2000 \mathrm{~m}^{2}$ ), only on $60 \%$ of the area of the forest culture, with belts of untouched canopy cover being 20 to $40 \mathrm{~m}$ in width [67]. Nevertheless, a better solution is to improve structure and stability with silvicultural measures already from first thinnings. Higher intensity thinings from below enhance stability indices [55, 68-70]. In mature forest cultures, which are comprised of trees with border stability indices (slenderness), a series of low intensity thinings are needed so the rest of trees would not be endangered, and also in order to leave the possibility for trees to positively react on space increase.

\section{CONCLUSIONS}

The presented preliminary results reveal the fact that avoidance or too low thinning intensities of anthropogenic spruce cultures in the first and second age class (until 40 years of age) permanently results with unfavourable shape and vitality of trees. It can be concluded that spruce cultures consisting of too slender trees should not be further maintained, but that they should be immediately replaced by more wind resistant stands (e.g. mixed species cultures). The reason for this is that they are simply cannot withstand at the present, and will not be able to withstand in the future, the influence of strong winds, especially if we consider the predicted increase of storm intensities and occurrences in the studied area and further stand destabilisation by silvicultural interventions in later development stages. If the complete destruction of studied spruce cultures, which happened recently, is taken into account, such cultures will not be able to produce expected financial or biological gains at all. We propose to get better insight into spruce tree characteristics and to evaluate their ability to withstand strong winds during the selection of trees for thinning, especially the horizontal spatial patter of such trees. The analyses of tree slenderness can also provide a good tool for predicting the critical wind speeds and the point of breakage of the managed spruce culture. In addition, tree slenderness proved to be a good predictor in this study, similar to other European studies from areas of frequent snow occurrences. Nevertheless, these are only preliminary results, which should be confirmed by further studies. In addition, proper silvicultural interventions early in the culture development are advised for achieving and maintaining optimal tree characteristics and vitality, providing favourable site conditions for subsequent replacement interventions and preventing early canopy losses.

\section{Acknowledgement}

We gratefully acknowledge the excellent technical support of employees of the state enterprise Croatian Forests Ltd., Forest Districts in Zagreb and Karlovac for their logistic support on the field site, and especially the employees of Forest Offices in Zagreb and Jastrebarsko.

\section{REFERENCES}

1. PAYN T, CARNUS J-M, FREER-SMITH P, KIMBERLEY $M$, KOLLERT W, LIU S, ORAZIO C, RODRIGUEZ L, NEVES SILVA L, WINGFIELD MJ 2015 Changes in planted forests and future global implications. Forest Ecol Manag 352 57-67. DOI: https://doi.org/10.1016/j.foreco.2015.06.021

2. EVANS J 2009 Planted Forests: Uses, Impacts and Sustainability. FAO, CABI, London, UK, $213 p$

3. LÜPKE B VON, AMMER C, BRUCIAMACCHIE M, BRUNNER A, CEITEL J, COLLET C, DEULEUZE C, DI PLACIDO J, et al., 2004 Silvicultural strategies for conversion. In: Spiecker H, Hansen J, Klimo E, Skovsgaard JP, Sterba H, Teuffel $\mathrm{K}$ von (eds) Norway spruce conversion - Options and consequences. European Forest Institute, Research Report, 18: $121-164$
4. TIJARDOVIĆ M, PERIĆ S 2013 Croatian Norway spruce cultures in European concept of culture management. Period Biol 115 (3): 355-361

5. ORŠANIĆ M 1995 Uspijevanje šumskih kultura obične smreke (Picea abies /L./ Karst.), crnoga bora (Pinus nigra Arn.) i europskog ariša (Larix decidua Mill.) na Zagrebačkoj gori. Glasnik za šumske pokuse 32: 1-89

6. TIJARODOVIĆ M 2015 Conversion of Norway spruce cultures (Picea abies /L./ Karst.) in Croatia. PhD thesis, Faculty of Forestry, University of Zagreb, Zagreb, Croatia, $277 p$

7. BRUECHER F, BECKER G, SPECK T 2000 The mechanics of Norway Spruce [Piceaabies (L.) Karst]: the mechanical properties of standing trees from different thinning regimes. Forest Ecol Manag 135 (1-3): 45-62. DOI: https:// doi.org/10.1016/S0378-1127(00)00297-8 
8. ANCELIN P, COURBAUD B, FOURCAUD T 2004 Development of an individual tree-based mechanical model to predict wind damage within forest stands. Forest Ecol Manag 203 (1-3): 101-121. DOI: https://doi.org/10.1016/i. foreco.2004.07.067

9. JONSSON M 2007 Live storage of Picea abies in Sweden after storm felling. Scand J Forest Res 22 (4): 344-350. DOI: https://doi.org/10.1080/02827580701478404

10. BOLTE A, AMMER C, LÖF $M$, MADSEN P, NABUURS G-J, SCHALL P, SPATHELF P, ROCK J 2009 Adaptive forest management in central Europe: Climate change impacts, strategies and integrative concept. Scand J Forest Res 24 (6): 473-482. DOI: https://doi. org/10.1080/02827580903418224

11. DUMROESE RK, PALIK BJ, STANTURF JA 2015 Forest restoration is forward thinking. J Forestry 113 (4): 430-432. DOI: https://doi.org/10.5849/jof.15-049

12. YOUSEFPOUR R, TEMPERLI C, JACOBSEN JB, THORSEN BJ, MEILBY H, LEXER MJ, LINDNER M, BUGMANN H, et al., 2017 A framework for modelling adaptive forest management and decision making under climate change. Ecol Soc 22 (4): 40. DOI: https://doi.org/10.5751/ES09614-220440

13. ZENG H, GARCÍA-GONZALO J, PELTOLA H, KELLOMÄKI S 2010 The effects of forest structure on the risk of wind damage at a landscape level in a boreal forest ecosystem. Ann Forest Sci 67 (1): 111. DOI: https://doi.org/10.1051/ forest/2009090

14. SEIDL R, RAMMER W, BLENNOW K 2014 Simulating wind disturbance impacts in forest landscapes: Tree - level heterogeneity matters. Environ Modell Softw 51: 1-11. DOI: https://doi.org/10.1016/i.envsoft.2013.09.018

15. WALLENTIN C, NILSSON U 2011 Initial effect of thinning on stand gross stem - volume production in a 33-year-old Norway spruce (Picea abies (L.) Karst.) stand in Southern Sweden. Scand J Forest Res 26 (11): 21-35. DOI: https://doi. org/10.1080/02827581.2011.564395

16. DEWAR RC, CANNELL MGR 1992 Carbon sequestration in the trees, products and soils of forest plantations: An analysis using UK examples. Tree Physiol 11 (1): 49-71. DOI: https://doi.org/10.1093/treephys/11.1.49

17. CREMER KW, BOROUGH CJ, MCKINNELL FH, CARTER PR 1982 Effects of stocking and thinning on wind damage in plantations. N Z J For Sci 12 (2): 244-268

18. SPATZ H-CH, BRUECHERT F 2000 Basic biomechanics of selfsupporting plants: wind loads and gravitational loads on a Norway spruce tree. Forest Ecol Manag 135 (1-3): 33-44. DOI: https://doi.org/10.1016/S0378-1127(00)00296-6

19. MASON WL 2002 Are irregular stands more windfirm? Forestry 75 (4): 347-355. DOI: https://doi.org/10.1093/ forestry/75.4.347

20. VIDAKOVIĆ M, FRANJIĆ J 2004 Gymnosperms. University of Zagreb, 3. edition, Zagreb, Croatia, 2004: 823

21. CROATIAN FORESTS LTD. 2008 Forest management plan for management unit "Jastrebarske prigorske šume". Department for forest measurement, Karlovac, 2006. Validity: 01.01.2008. - 31.12.2017

22. CROATIAN FORESTS LTD. 2008 Forest management plan for management unit "Bistranska Gora". Department for forest measurement, Zagreb, 2006. Validity: 01. 01. 2008. - 31. 12. 2017

23. PRETZSCH H 2009 Forest Dynamics, Growth and Yield: From Measurement to Model. Springer-Verlag Berlin Heidelberg, Germany, $337 \mathrm{p}$

24. STATSOFT, INC 2007 Electronic Statistics Textbook. Tulsa, OK: StatSoft. URL: http://www.statsoft.com/textbook/ stathome.html.
25. ORŠANIĆ M 2003 Afforestation, current status and perspective in global development. Šumar List 127: 35-40 (in Croatian with English summary)

26. LARSEN JB 1995 Ecological stability of forests and sustainable silviculture. Forest Ecol Manag 73(1-3): 85-96. DOI: https://doi.org/10.1016/0378-1127(94)03501-M

27. DOBBERTIN M 2002 Influence of stand structure and site factors on wind damage comparing the storms Vivian and Lothar. For Snow Landsc Res 77 (1/2): 187-205

28. ROTHE A, BINKLEY D 2001 Nutritional interactions in mixed species forests: a synthesis. Can J Forest Res 31 (11): 18551870. DOI: https://doi.org/10.1139/x01-120

29. PRETZSCH H 2003 The elasticity of growth in pure and mixed stands of Norway spruce (Picea abies [L.] Karst.) and common beech (Fagus sylvatica L.). J Forest Sci 49 (11): 491-501. DOI: https://doi.org/10.17221/4721-jfs

30. HECTOR A, BAGCHI R 2007 Biodiversity and ecosystem multifunctionality. Nature 448: 188-190. DOI: https://doi. org/10.1038/nature05947

31. THAM A 1994 Crop plans and yield predictions for Norway spruce (Picea abies (L.) Karst.) and birch (Betula pendula Roth \&Betula pubescens Ehrh.) mixtures. Studi Forest Sueci 195: $21 \mathrm{p}$

32. FRIVOLD LH, FRANK J 2002 Growth of mixed birch - coniferous stands in relation to pure coniferous stands at similar sites in south - eastern Norway. Scand J Forest Res 17 (2): 139-149. DOI: https://doi. org/10.1080/028275802753626782

33. MILES J 1986 What are the effects of trees on soils? In: Jenkins D., (eds) Trees and wildlife in the Scottish uplands. NERC/ITE, 55 - 62. (ITE Symposium, 17). 1986 NERC. URL: http://nora.nerc.ac.uk/5293/ (February 2018)

34. HEITZ R 2000 Reconversion of Norway spruce (Picea abies (L.) Karst.) stands into mixed forests: effects on soil properties and nutrient fluxes. In: Hasenauer $\mathrm{H}(e d)$ Forest ecosystem restoration: ecological and economical impacts of restoration processes in secondary coniferous forests. Proceedings of the International Conference, Vienna, Austria, 10-12 April 2000, pp 119-125

35. BRANDTBERG P O, LUNDKVIST H, BENGTSSON J 2000 Changes in forest - floor chemistry caused by a birch admixture in Norway spruce stands. Forest Ecol Manag 130 (1-3): 253-264. DOI: https://doi.org/10.1016/S03781127(99)00183-8

36. PRÉVOSTO B, BALANDIER P 2007 Influence of nurse birch and Scots pine seedlings on early aerial development of European beech seedlings in an open - field plantation of Central France. Forestry 80 (3): 253-264. DOI: https://doi. org/10.1093/forestry/cpm017

37. NOVAK J, SLODIČAK M 2009 Thinning experiment in the spruce and beech mixed stands on the locality naturally dominated by beech - growth, litter - fall and humus. Journal of Forest Science 55 (5): 224-233

38. KUPKA I, PODRÁZSKÝ V 2011 Species composition effects of forest stands on afforested agricultural land on the soil properties. Scientia Agriculturae Bohemica 42 (1): 19-23

39. ABRAHAMSEN G, HORNTVEDT R, TVEITE B 1976 Impacts of acid precipitation on coniferous forest ecosystems. In: Dochinger LS, Seliga TA (eds) Proceedings of the first international symposium on acid precipitation and the forest ecosystem. Gen. Tech. Rep. NE - 23, U.S. Department of Agriculture, Forest Service, Northeastern Forest Experiment Station. URL: http://www.treesearch.fs.fed.us/ pubs/11513 (February 2013).

40. HOVLAND J, ABRAHAMSEN G, OGNER G 1980 Effects of artificial acid rain on decomposition of spruce needles and on mobilisation and leaching of elements. Plant Soil 56 (3): 365-378. DOI: https://doi.org/10.1007/BF02143031 
41. SCHULZE E-D 1989 Air Pollution and Forest Decline in a Spruce (Picea abies). For Sci 244: 776-783. DOI: https://doi. org/10.1126/science.244.4906.776

42. BERGER TW, UNTERSTEINER H, SCHUME H, JOST G 2008 Throughfall fluxes in a secondary spruce (Picea abies), a beech (Fagus sylvatica) and a mixed spruce - beech stand. Forest Ecol Manag 255 (3-4): 605-618. DOI: https://doi. org/10.1016/i.foreco.2007.09.030

43. BARRELET T, ULRICH A, RENNENBERG H, ZWICKY CN, KRÄHENBÜHL U 2008 Assessing the suitability of Norway spruce wood as an environmental archive for sulphur. Environ Pollut 156 (3): 1007-1014. DOI: https://doi. org/10.1016/i.envpol.2008.05.004

44. BRANKOVIĆ Č, GÜTTLER I, PATARČIĆ M, SRNEC L 2010 Climate Change Impacts and Adaptation Measures Climate Change scenario. In: Fifth National Communication of the Republic of Croatia under the United Nation Framework Convention on the Climate Change, Ministry of Environmental Protection, Physical Planning and Construction, pp 152-166. URL: http://klima.hr/razno/ publikacije/klimatske promjene.pdf (January 2018)

45. BRANKOVIĆ Č, PATARČIĆ M, GÜTTLER I, SRNEC L 2012 Near - future climate change over Europe with focus on Croatia in an ensemble of regional climate model simulations. Climate Res 52 (1): 227-251. URL: http://www.int-res.com/ articles/cr oa/c052p227.pdf (January 2018)

46. PELTOLA H, KELLOMAKI S, VAISANEN H, IKONEN V-P 1999 A mechanistic model for assessing the risk of wind and snow damage to single trees and stands of Scots pine, Norway spruce and birch. Can J For Res 29 (6): 647-661. DOI: https://doi.org/10.1139/x99-029

47. PRETZSCH H 2013 Facilitation and competition in mixed species forests analysed along an ecological gradient. Nova Acta Leopol 114 (391): 159-174

48. IPCC 2007 Fourth Assessment Report. Official IPCC website: www.ipcc.ch

49. BRUNNER A, HAHN K, BIBER P, SKOVSGAARD JP 2006 Conversion of Norway spruce: A case study in Denmark based on silvicultural scenario modelling. Sustain For Manag pp 343-371. DOI: https://doi.org/10.1007/3-54031304-4 20

50. IKONEN V-P, PELTOLA H, WILHELMSSON L, KILPELÄINEN A, VÄISÄNEN H, NUUTINEN T, KELLOMÄKI S 2008 Modelling the distribution of wood properties along the stems of Scots pine (Pinus sylvestris L.) and Norway spruce (Picea abies (L.) Karst.) as affected by silvicultural management. Forest Ecol Manag 256 (6): 1356-1371. DOI: https://doi. org/10.1016/j.foreco.2008.06.039

51. GARDINER B, BYRNE K, HALE S, KAMIMURA K, MITCHELL S, PELTOLA H, RUEL JC 2008 A review of mechanistic modelling of wind damage risk to forests. Forestry 81 (3): 447-461. DOI: https://doi.org/10.1093/forestry/cpn022

52. BLENNOW $K$, ANDERSSON $M$, SALLNÄS O, OLOFSSON E 2010 Climate change and the probability of wind damage in two Swedish forests. Forest Ecol Manag 259 (4): 818830. DOI: https://doi.org/10.1016/j.foreco.2009.07.004

53. KANYAMA AC, BLENNOW K 2014 Evaluating the Local Climate Impacts Profile tool for assessing local impacts of extreme weather events. J Geogr Nat Disast 4: 122. DOI: https://doi.org/10.4172/2167-0587.1000122

54. NYKÄNEN M-L, PELTOLA $H$, QUINE CP, KELLOMÄKI S, BROADGATE M 1997 Factors affecting snow damage of trees with particular reference to European conditions. Silva Fenn 31 (2): 193-213. DOI: https://doi.org/10.14214/ $\underline{\text { sf.a8519 }}$
55. WONN HT, O'HARA KL 2001 Height - diameter ratios and stability relationships for four northern Rocky Mountain tree species. West J Appl For 16 (2): 87-94

56. VAUGHN N 2007 An individual - tree model to predict the annual growth of young stands of Douglas - fir (Pseudotsuga menziesii (Mirbel) Franco) in the Pacific Northwest. Masters thesis, University of Washington, USA

57. TALKKARI A, PELTOLA H, KELLOMAKI S, STRANDMAN H 2000 Integration of component models from the tree, stand and regional levels to assess the risk of wind damage at forest margins. Forest Ecol Manag 135 (1-3): 303-313. DOI: https://doi.org/10.1016/S0378-1127(00)00288-7

58. FORMANEK P, VRANOVÁ V 2002 A contribution to the effect of liming on forest soils: review of literature. Journal of Forest Science 49 (4): 182-190

59. PELTOLA H 2006 Mechanical stability of trees under static loads. Am J Bot 93 (10): 1501-1511. DOI: https://doi. org/10.3732/ajb.93.10.1501

60. WALLENTIN C, NILSSON U 2011 Initial effect of thinning on stand gross stem-volume production in a 33-year-old Norway spruce (Picea abies (L.) Karst.) stand in Southern Sweden. Scand J Forest Res 26 (11): 21-35. DOI: https://doi. org/10.1080/02827581.2011.564395

61. SZYMURA TH 2005 Silver fir sapling bank in seminatural stand: Individuals architecture and vitality. Forest Ecol Manag, 212 (1-3): 101-108. DOI: https://doi.org/10.1016/i. foreco.2005.03.003

62. DOBBERTIN M, BRANG P 2001 Crown Defoliation Improves Tree Mortality Models. Forest Ecol Manag 141 (3): 271284. DOI: https://doi.org/10.1016/S0378-1127(00)00335$\underline{2}$

63. ZIERL B 2004 A simulation study to analyse the relations between crown condition and drought in Switzerland. Forest Ecol Manag 188 (1-3): 25-38. DOI: https://doi. org/10.1016/i.foreco.2003.07.019

64. POLÁK T, ROCK BN, CAMPBELL PE, SOUKUPOVÁ J, SOLCOVA B, ZVÁRA K, ALBRECHTOVA J 2006 Shoot Growth Processes, Assessed by Bud Development Types, Reflect Norway Spruce Vitality and Sink Prioritization. Forest Ecol Manag 225 (1-3): 337-348. DOI: https://doi.org/10.1016/j. foreco.2006.01.027

65. GARDINER BA, STACEY GR 1995 Designing Forest Edges to Improve Wind Stability. Forestry Commission Technical paper 16, Forestry Commission, Edinburgh, Scotland, UK

66. GARDINER BA, STACEY GR, BELCHER RE, WOOD CJ 1997 Field and wind tunnel assessments of the implications of respacing and thinning for tree stability. Forestry 70 (3): 233-252. DOI: https://doi.org/10.1093/forestry/70.3.233

67. HERING S, IRRGANG S 2005 Conversion of substitute tree species stands and pure spruce stands in the Ore Mountains in Saxony. Journal of Forest Science, 51 (11): 519-525

68. SLODIČÁK M, NOVÁK J 2003 Thinning experiments in Norway spruce stands after 40 years of investigation - 1st series. Journal of Forest Science 49 (2): 45-73

69. SLODICAK M, NOVAK J 2006 Silvicultural measures to increase the mechanical stability of pure secondary Norway spruce stands before conversion. Forest Ecol Manag 224 (3): 252-257. DOI: https://doi org/10.1016/j. foreco.2005.12.037

70. OLOFSSON E, BLENNOW K 2005 Decision support for identifying spruce forest stand edges with high probability of wind damage. Forest Ecol Manag 207 (1-2): 87-98. DOI: https://doi.org/10.1016/i.foreco.2004.10.019 